\title{
Serum magnesium and copper levels in Bangladeshi women with gestational diabetes mellitus
}

\author{
Farzana Akonjee Mishu and MA Muttalib \\ Department of Biochemistry, Mymensingh Medical College, Mymensingh, Bangladesh
}

\begin{abstract}
Background and objectives: Alteration of magnesium $(\mathrm{Mg})$ and copper $(\mathrm{Cu})$ concentrations in blood has been observed in normal pregnancy as well as in gestational diabetes mellitus (GDM). The present study was aimed to evaluate the serum $\mathrm{Mg}$ and $\mathrm{Cu}$ levels in Bangladeshi women with GDM in their second and third trimester of pregnancy.
\end{abstract}

Methods: The study was conducted at Mymensingh Medical College Hospital from July 2013 to June 2014. Pregnant women, in their second and third trimester, attending the outpatient department of Obstetrics and Gynecology and the Department of Endocrinology of Mymensingh Medical College Hospital were enrolled by purposive sampling technique. GDM was diagnosed on the basis of oral glucose tolerance test (OGTT) as defined in WHO criteria 2013. Blood glucose was estimated by enzymatic GOD-PAP colorimetric method. The cut off value for fasting plasma glucose level was $\geq 6.1 \mathrm{mmol} / \mathrm{L}$ or $\geq 7.8 \mathrm{mmol} / \mathrm{L} 2$ hours after glucose load. Serum $\mathrm{Cu}$ was estimated by 3, 5-DiBr-PAESA method and Mg by Xylidyl Blue-I Method as per manufacturer's instruction.

Results: A total of 172 pregnant women in their second and third trimester were enrolled. Out of 172 participants, 86 had GDM and 86 were normoglycemic (control). The mean age of GDM and control groups was $28.6 \pm 3.2$ years and $27.3 \pm 3.1$ years respectively. The BMI was $26.4 \pm 1.5 \mathrm{~m} / \mathrm{kg}^{2}$ and $26.3 \pm 1.3 \mathrm{~m} / \mathrm{kg}^{2}$. Serum $\mathrm{Mg}$ level was significantly low $(\mathrm{p}<0.001)$ in $2^{\text {nd }}$ and $3^{\text {rd }}$ trimesters in GDM cases $(1.39 \pm 0.26 \mathrm{mg} / \mathrm{dl}$ and $0.93 \pm 0.15 \mathrm{mg} / \mathrm{dl})$ compared to control group $(1.67 \pm 0.3 \mathrm{mg} / \mathrm{dl}$ and $1.67 \pm 0.31 \mathrm{mg} / \mathrm{dl})$. On the contrary, serum $\mathrm{Cu}$ levels in GDM cases were significantly $(\mathrm{p}<0.002)$ higher in both trimesters $(224 \pm 333.8 \mu \mathrm{g} / \mathrm{dl}$ and $243.91 \pm 6.89 \mu \mathrm{g} / \mathrm{dl})$ compared to those without GDM $(220.1 \pm 7.6 \mu \mathrm{g} / \mathrm{dl}$ and $234.9 \pm 4.6$ $\mu \mathrm{g} / \mathrm{dl})$. There was significant $(\mathrm{p}<0.001)$ increase of serum $\mathrm{Cu}$ levels in $3^{\text {rd }}$ trimester compared to $2^{\text {nd }}$ trimester in both GDM and non GDM cases.

Conclusion: There was distinct alteration of serum $\mathrm{Mg}$ and $\mathrm{Cu}$ levels in GDM compared to normal pregnancy.

IMC J Med Sci 2017; 11(1): 25-28

\section{Introduction}

Gestational diabetes mellitus is defined as carbohydrate intolerance resulting in hyperglycemia, with first onset or detection during pregnancy $[1,2]$. Usually initiation of GDM is in middle and late gestational period and continues to term [3]. Glucose intolerance usually returns to normal range within six weeks after delivery [4]. Approximately 1-14 \% of all pregnancies are complicated by GDM [4]. The prevalence of GDM among Bangladeshi pregnant mothers has been reported as $9.7 \%$ [5]. Pregnancy is associated with physiological changes that result in increased plasma volume and decreased concentrations of plasma proteins and micronutrients [6]. It is a time

\section{Address for Correspondence:}

Dr. Farzana Akonjee Mishu, Department of Physiology and Molecular Biology, BIRDEM General Hospital, 122 Kazi Nazrul Islam Avenue, Dhaka, Bangladesh. Email: farzanamishu@yahoo.co.uk 
of increased nutritional needs, both to support the rapidly growing fetus and the changes occurring in mother during pregnancy. Different researchers have demonstrated that macro and micro nutrients are essential for the optimum development of fetus. Among the micronutrients, $\mathrm{Cu}$ is important, especially early in the life for the development and maintenance of fetal organs and tissues. Deficiencies of $\mathrm{Cu}$ have been implicated in infertility, pregnancy wastage, congenital abnormalities, still birth and low birth weight $[7,8]$. Serum $\mathrm{Cu}$ values in healthy pregnant women increases with gestational period [9]. Serum $\mathrm{Cu}$ has been found to be significantly higher in GDM cases as compared to euglycemic healthy pregnant women [10]. Earlier studies reported higher level of serum $\mathrm{Cu}$ in full term healthy Bangladeshi pregnant women compared to non pregnant women $[11,12]$. Likewise, $\mathrm{Mg}$ has been found to be linked to fetal and maternal wellbeing. $\mathrm{Mg}$ deficiency during pregnancy is associated with intrauterine growth retardation and metabolic syndrome in later life of the offspring $[13,14]$. There is report of low and variable serum $\mathrm{Mg}$ level during second and third trimester of normal pregnancy [15]. It has been found that serum $\mathrm{Mg}$ is depleted at a greater extent in women with GDM [16]. However, there is no systematic study regarding the serum levels of $\mathrm{Cu}$ and $\mathrm{Mg}$ in Bangladeshi pregnant women with GDM. Therefore, the present study was undertaken to determine the serum $\mathrm{Cu}$ and $\mathrm{Mg}$ levels in second and third trimester of pregnancy in Bangladeshi women with GDM.

\section{Materials and Methods}

The study was conducted at Mymensingh Medical College Hospital from July 2013 to June 2014 to evaluate the serum level of magnesium and copper in pregnant women with GDM. The study protocol was approved by the institutional review committee and written informed consent was obtained from all the participants prior to their enrolment into this study.

Study population and collection of samples: Pregnant women, in their second and third trimester, attending the outpatient department of
Obstetrics and Gynecology and the Department of Endocrinology of Mymensingh Medical College Hospital were enrolled by purposive sampling technique. Pregnant women with the previous history of diabetes, hypertension and other endocrine disorders were excluded from the study. Data were collected in a predesigned data collection sheet. The variables included were - age, height, weight, duration of gestation, family history of diabetes, previous history of pregnancy and gestational diabetes mellitus. About $5 \mathrm{ml}$ of blood was collected aseptically with venipuncture from all participants for OGTT and estimation of serum $\mathrm{Cu}$ and $\mathrm{Mg}$ levels.

Estimation serum glucose, $\mathrm{Cu}$ and $\mathrm{Mg}$ : Blood glucose was estimated by enzymatic GOD-PAP colorimetric method [17]. GDM was diagnosed on the basis of OGTT as defined in WHO criteria $2013[1,18]$. The cut off value for fasting plasma glucose level was $\geq 6.1 \mathrm{mmol} / \mathrm{L}$ or $\geq 7.8 \mathrm{mmol} / \mathrm{L}$ 2 hours after glucose load. Serum $\mathrm{Cu}$ and $\mathrm{Mg}$ were determined by commercial colorimetric assay kits obtained from Japan Institute for the Control of Aging (JaICA), Nikken Seal Co., Ltd, Japan. Serum $\mathrm{Cu}$ was estimated by 3, 5-DiBr-PAESA method and $\mathrm{Mg}$ by Xylidyl Blue-I Method as per manufacturer's instruction.

The results were analyzed and values were expressed as mean $\pm \mathrm{SD}$. The level of significance was determined by employing Student's t test.

\section{Result}

A total of 172 pregnant women in their second and third trimester were enrolled in the study of which 86 had GDM and 86 were normoglycemic by OGTT test. Pregnant women without GDM (normoglycemic)

Table-1: Age and BMI of study population

\begin{tabular}{lcc}
\hline Group & Age in yrs & BMI (m/. $\left.\mathbf{k g}^{\mathbf{2}}\right)$ \\
\hline GDM & $28.6 \pm 3.2$ & $26.4 \pm 1.5$ \\
Control & $27.3 \pm 3.1$ & $26.3 \pm 1.3$ \\
p value & 0.778 & 0.774 \\
\hline
\end{tabular}

GDM- Gestational diabetes mellitus; Control- Pregnant women without GDM (Euglycemic) 
Table-2: Serum concentration of $\mathrm{Mg}$ and $\mathrm{Cu}$ in GDM and euglycemic pregnant women

\begin{tabular}{|c|c|c|c|c|c|c|}
\hline \multirow[b]{2}{*}{ Group } & \multicolumn{3}{|c|}{$\begin{array}{l}\text { Mean } \pm \text { SD concentration of } \mathrm{Mg} \\
(\mathrm{mg} / \mathrm{dl}) \text { in }\end{array}$} & \multicolumn{3}{|c|}{ Mean \pm SD concentration of $\mathrm{Cu}(\mu \mathrm{g} / \mathrm{dl})$ in } \\
\hline & $\begin{array}{c}2^{\text {nd }} \\
\text { Trimester } \\
\end{array}$ & $\begin{array}{c}3^{\text {rd }} \\
\text { Trimester }\end{array}$ & Total & $\begin{array}{c}\text { 2nd } \\
\text { Trimester }\end{array}$ & $\begin{array}{c}\text { 3rd } \\
\text { Trimester } \\
\end{array}$ & Total \\
\hline GDM & $1.4 \pm 0.3$ & $0.9 \pm 0.2$ & $1.2 \pm 0.3$ & $224.3 \pm 3.8$ & $243.9 \pm 6.9$ & $237.0 \pm 10.0$ \\
\hline Control & $1.7 \pm 0.3$ & $1.7 \pm 0.3$ & $1.7 \pm 0.3$ & $220.1 \pm 7.6$ & $234.9 \pm 4.6$ & $234.6 \pm 4.2$ \\
\hline $\mathrm{p}$ value & 0.001 & 0.001 & 0.001 & 0.002 & 0.001 & 0.042 \\
\hline
\end{tabular}

were considered as control group. The mean age of GDM and control groups were $28.6 \pm 3.2$ years and $27.3 \pm 3.1$ years while the mean BMI was $26.4 \pm 1.5$ $\mathrm{m} / \mathrm{kg}^{2}$ and $26.3 \pm 1.3 \mathrm{~m} / \mathrm{kg}^{2}$ respectively (Table-1). Serum $\mathrm{Mg}$ level was significantly low $(\mathrm{p}<0.001)$ in $2^{\text {nd }}$ and $3^{\text {rd }}$ trimesters in GDM cases $(1.4 \pm 0.3$ $\mathrm{mg} / \mathrm{dl}$ and $0.9 \pm 0.2 \mathrm{mg} / \mathrm{dl}$ ) compared to control group $(1.7 \pm 0.3 \mathrm{mg} / \mathrm{dl}$ and $1.7 \pm 0.3 \mathrm{mg} / \mathrm{dl})$. The serum $\mathrm{Mg}$ level declined in $3^{\text {rd }}$ trimester compared to $2^{\text {nd }}$ trimester in GDM cases while there was no such change in cases without GDM. On the contrary, serum $\mathrm{Cu}$ levels in GDM cases were significantly $(\mathrm{p}<0.002)$ higher in both trimesters $(224 \pm 3.8 \mu \mathrm{g} / \mathrm{dl}$ and $243.9 \pm 6.9 \mu \mathrm{g} / \mathrm{dl})$ compared to those without GDM $(220.1 \pm 7.6 \mu \mathrm{g} / \mathrm{dl}$ and $234.9 \pm 4.6 \mu \mathrm{g} / \mathrm{dl})$. There was significant $(\mathrm{p}<0.01)$ rise of serum $\mathrm{Cu}$ levels in $3^{\text {rd }}$ trimester compared to $2^{\text {nd }}$ trimester in both GDM and non GDM cases (Table-2).

\section{Discussion}

In this study, we have estimated serum $\mathrm{Mg}$ and $\mathrm{Cu}$ levels in pregnant women with GDM and in healthy pregnant women (euglycemic control). Serum $\mathrm{Mg}$ concentration in women with GDM was significantly low compared to that of control. The decrease in serum $\mathrm{Mg}$ might be caused by osmotic diuresis and by indirect hormonal effects. The low serum $\mathrm{Mg}$ levels seen in the diabetic population could be a consequence of insulin resistance and low dietary $\mathrm{Mg}$ intake and decreased intestinal absorption [16].

In the present study, the serum concentration of $\mathrm{Cu}$ in women with GDM were significantly higher $(\mathrm{p}<0.001)$ compared to the controls. The possible causes of high serum $\mathrm{Cu}$ concentration in GDM cases could be due to the hormonal, metabolic and enzymatic changes in pregnancy. Increased $\mathrm{Cu}$ level in GDM cases could be due to decreased insulin sensitivity in GDM [10]. Though studies have found increased level of copper in GDM, others have found no statistically significant difference of serum $\mathrm{Cu}$ concentrations between healthy pregnant women and women with GDM [19]. However, pregnant women with GDM should be carefully monitored for adverse effects of increased copper.

The present study has revealed that there is pronounced alteration of serum $\mathrm{Mg}$ and $\mathrm{Cu}$ levels in GDM cases compared to normal pregnancy. Therefore, further study should be done to find out the underlying mechanism of alteration of serum $\mathrm{Mg}$ and $\mathrm{Cu}$ levels in DGM.

\section{References}

1. Diagnostic criteria and classification of hyperglycaemia first detected in pregnancy: a World Health Organization Guideline. Diabetes Res Clin Pract. 2014; 103: 341-3632.

2. Buckley BS, Harreiter J, Damm P, Corcoy R, Chico A, Simmons D, Vellinga A, et al. Gestational diabetes mellitus in Europe: prevalence, current screening practice and barriers to screening. A review. Diabet Med. 2012: 29(7): 844-54. doi: 10.1111/j.1464-5491. 2011.03541.x.

3. Gokcel A, Bagis T, Killicadag EB, Tarim E, Guvener N. Comparison of the criteria for gestational diabetes mellitus by NDDG and Carpenter and Coustan, and the outcomes of pregnancy. J Endocrinol Invest. 2002; 25: 357-61.

4. Kim C, Newton KM, Knopp RH. Gestational diabetes and the incidence of type 2 diabetes. Diabetes Care. 2002; 25: 1862-8. 
Mishu FA and Muttalib MA et al.

5. Jesmin S, Akhter S, Akashi H, Al-Mamun A, Rahman MA, Islam MM, et al. Screening for gestational diabetes mellitus and its prevalence in Bangladesh. Diabetes Res Clin Pract. 2014; 103(1): 57-62.

6. Ladipo OA. Nutrition in pregnancy: mineral and vitamin supplements. Am J clin Nutr. 2000; 72: 280-290.

7. Ashworth CJ, Antipatis C. Micronutrient programming of development throughout gestation. Reproduction 2001; 122(4): 527-535.

8. Keen CL, Uriu-Hare JY, Hawk SN, Jankowski MA, Daston GP, Kwik-Uribe CL. Effect of copper deficiency on prenatal development and pregnancy outcome. $\mathrm{Am} \mathrm{J}$ Clin Nutr. 1998; 67(suppl):1003S-1011S.

9. Vukelić J, Kapamadžija A, Petrović D, Grujić Z, Novakov-Mikić A, Kopitović V, Bjelica A. Variations of Serum Copper Values in Pregnancy. Srp Arh Celok Lek. 2012; 140(12): $42-46$.

10. Asha D, Nanda N, Daniel M, Sen SK, Ranjan T. Association of serum copper level with fasting serum glucose in south Indian women with gestational diabetes mellitus. Int $J$ Clin Exp Physiol. 2014; 1(4): 298-302.

11. Sultana M, Jahan N, Sultana N, Ali ML, Sunyal DK, Al Masud MA. Serum Copper level in Term women. J Dhaka National Med Coll Hosp. 2011; 17(02): 18-20.

12. Noor N, Jahan N, Sultana N. Serum Copper and Plasma Protein Status in Normal Pregnancy. J Bangladesh Soc Physiol. 2012; 7(2): 66-71.
13. Goker TU, Tasdemir N, Kilic S, Abali R, Celik C, Gulerman HC. Alterations of Ionized and total Magnesium levels in Pregnant Women with Gestational Diabetes Mellitus. Gynecol Obstet Invest. 2015; 79: 19-24.

14. Takaya J,Yamato F and Kaneko K. Possible relationship between low birth weight and magnesium status: from the standpoint of "foetal origin" hypothesis. Magnesium Res 2006; 19: 630-639.

15. Baloch GH, Shaikh K, Jaffery MH, Abbas T, Das CM, Devrajan BR, et al. Serum magnesium level during pregnancy. World Appl Sci J. 2012; 17(8): 1005-1008.

16. Bardicef M, Bardicef O, Sorokin Y, Altura BM, Altura BT, Cotton DB and Resnick LM. Extracellular and intracellular magnesium depletion in pregnancy and gestational diabetes. Am J Obstet and Gynecol. 1995; 172(3): 1009-1013.

17. Trinder P. Determination of glucose in blood using glucose oxidase with an alternative oxygen acceptor. Ann.Clin. Biochem 1969; 6: 24-7

18. WHO Consultation: definition, diagnosis and classification of diabetes mellitus and its complications: report of a WHO Consultation. Part 1: diagnosis and classification of diabetes mellitus. Geneva, WHO/NCD/NCS/99. 2: World Health Organization; 1999.

19. Loven A, Romem Y, Pelly IZ, Holeberg G, Agam G. Copper metabolism--a factor in gestational diabetes? Clin chim Acta. 1992; 213(1-3):51-59. 